\title{
Serum C-reactive protein concentrations in patients with pulmonary sarcoidosis
}

\author{
CHARLES R K HIND, KEVIN C FLINT, BARRY N HUDSPITH, \\ DAVID FELMINGHAM, JONATHAN BROSTOFF, NORMAN McI JOHNSON
}

From the Departments of Medicine and Immunology, Middlesex Hospital, and the Department of Microbiology University College Hospital, London

ABSTRACT In a prospective study serum C-reactive protein concentrations were measured in nineit patients with "active" pulmonary sarcoidosis (as assessed by bronchoalveolar lavage lymphocyto心 counts, gallium-67 lung scanning, and serial pulmonary function testing), and in five patients with "inactive" disease. Active pulmonary sarcoidosis was associated either with no rise or with only a modest rise in serum C-reactive protein concentrations. In contrast, serum C-reactive protein con centrations in 12 patients with sputum positive pulmonary tuberculosis were considerably raised Serum C-reactive protein may thus provide a valuable test in the differentiation of sarcoidosis fromo $0^{\circ}$ conditions which it may mimic and which are known to induce an acute phase response.

Active pulmonary sarcoidosis is characterised by granuloma formation and an alveolitis arising primarily from activated $T$ helper lymphocytes and mononuclear phagocytes. ${ }^{1-3}$ The mononuclear phagocytes are the building blocks of granulomas and are thought to have a central role in initiating and maintaining the $\mathrm{T}$ lymphocyte activation by secretion of the mediator interleukin-1 (IL-1). ${ }^{45}$ Consistent with this hypothesis is the finding that alveolar macrophages from patients with active pulmonary sarcoidosis release greater amounts of IL-1 than do those with inactive disease. ${ }^{6}$ This suggests that the degree of macrophage activation, and hence IL-1 production, may correlate with the activity of the lung disease.

Direct measurement of IL-1 is relatively recent and not well standardised. ${ }^{5}$ Indirect measurement, however, of circulating IL-1 levels is possible since this peptide plays a part in triggering the hepatic synthesis of several acute phase proteins, including the classical acute phase reactant C-reactive protein. ${ }^{57}$ Various techniques are now available for the precise and rapid estimation of the serum C-reactive protein concentration, and we have therefore investigated its poss-

*Dr KC Flint was killed in a traffic accident on 20 January 1986.

Address for reprint requests: Dr CRK Hind, Royal Liverpool Hospital, Liverpool L78XP.

Accepted 20 January 1987 ible role in monitoring disease activity in patients wit/o pulmonary sarcoidosis.

\section{Methods}

\section{PATIENTS}

We studied 14 patients (six male, eight female; mear? age 42 years, range 19-59) with pulmonary sarcoid osis. There were five caucasian, four West Indian and four Asian patients, and one Iranian. All had histox logically proved sarcoidosis (11 cases) or a positive Kveim test, or both (10 cases). At the time of assessment of the activity of their pulmonary sarcoidosis? the mean duration of symptoms was 61 months (range 1-132), and only one patient was taking pred응 nisolone. Two patients were at chest radiographio stage 0 (no apparent abnormality), four were at stage: I (hilar adenopathy only), five were at stage II (hilan adenopathy and pulmonary infiltrates), and three were at stage III (pulmonary infiltrates only). Twelve patients also had extrathoracic disease (lymphe adenopathy, three cases; skin, two cases; liver, twe cases; uveitis, two cases; lymphadenopathy with epio scleritis, splenomegaly, parotid enlargement, one casథ of each).

\section{ASSESSMENT OF DISEASE ACTIVITY}

Patients were divided into two groups, according tळ the activity of the lung disease as assessed both big bronchoalveolar lavage cell counts and gallium- $6 \mathbb{7}$ citrate scanning ${ }^{8}$ and by serial pulmonary function 
testing. ${ }^{10}$ Patients were considered to have "active" pulmonary sarcoidosis if more than $28 \%$ of their lavage cells were $T$ lymphocytes and a gallium-67 lung scan was positive. Patients were classified as having "inactive" pulmonary sarcoidosis if $28 \%$ or less of their lavage cells were $T$ lymphocytes and a gallium67 scan was negative. In addition, standard pulmonary function tests were performed both before and at the time of the lavage and gallium scanning, and also repeated three and six months later. ${ }^{10}$

\section{BLOOD INVESTIGATIONS}

Blood was taken for measurement of the serum Creactive protein concentration at the time of the bronchoalveolar lavage, when the erythrocyte sedimentation rate (ESR) and serum angiotensin converting enzyme (SACE) concentration were also measured in some patients. ${ }^{1112}$ Serum C-reactive protein was assayed by enzyme immunoassay (EMIT; Syva Co, Palo Alto, California). Intra-assay and interassay replicates gave results with a coefficient of variation of less than $10 \%$. With this assay all 30 normal healthy people with a history of previous pulmonary tuberculosis had a serum C-reactive protein concentration of less than $10 \mathrm{mg} / \mathrm{l}$ (CRK Hind and D Felmingham, unpublished observations), which is the upper limit of the normal range as indicated by the assay's manufacturers and also as reported by previous workers using radioimmunoassay techniques. ${ }^{13}$

For comparison, blood was also taken for serum C-reactive protein measurement from 12 consecutive patients with sputum positive pulmonary tuberculosis before they started antituberculous chemotherapy. All these patients had pulmonary infiltrates or cavitation (or both) on their chest radiographs.

\section{STATISTICAL ANALYSIS}

Differences in results of the various objective measurements between groups of patients were sought by means of the Wilcoxon rank sum test.

\section{Results}

\section{DISEASE ACTIVITY}

Nine patients had "active" pulmonary sarcoidosis as defined above. In addition, in four of six patients a serial decrease in forced vital capacity (FVC) and transfer factor for carbon monoxide (TLCO) was documented, and in all three patients subsequently treated with corticosteroids there was an increase in their FVC and TLCO. SACE levels were raised in five of six patients, and the ESR in two of six (40 and $43 \mathrm{~mm}$ in the first hour: serum C-reactive protein concentration 0 and $24 \mathrm{mg} / \mathrm{l}$ respectively). None of these patients had biochemical evidence to suggest hepatic sarcoidosis.
Five patients had "inactive" pulmonary sarcoidosis and serial measurements of FVC in all five showed no change over six months. SACE concentrations were minimally raised in both patients tested (68 and $72 \mathrm{nmol} / \mathrm{min} / \mathrm{ml}$ ), and all four tested had a normal ESR. Both patients with histologically proved hepatic granulomas fell into this group.

\section{SERUM C-REACTIVE PROTEIN CONCENTRATION}

The serum C-reactive protein concentration was normal in seven of nine patients with "active" pulmonary sarcoidosis, and in all five patients in the "inactive" group (figure). The two patients with "active" pulmonary disease and a modestly raised serum Creactive protein concentration (14 and $24 \mathrm{mg} / \mathrm{l}$; ESR 15 and $43 \mathrm{~mm}$ in one hour respectively) both had anterior uveitis, a condition associated with an acute phase response in its own right. ${ }^{14}$

In contrast, the serum $\mathrm{C}$-reactive protein concentration was raised in all 12 patients with sputum positive pulmonary tuberculosis (mean 102, range $37-205 \mathrm{mg} / \mathrm{l}$ ) (figure).

\section{Discussion}

Increased C-reactive protein production is a non-

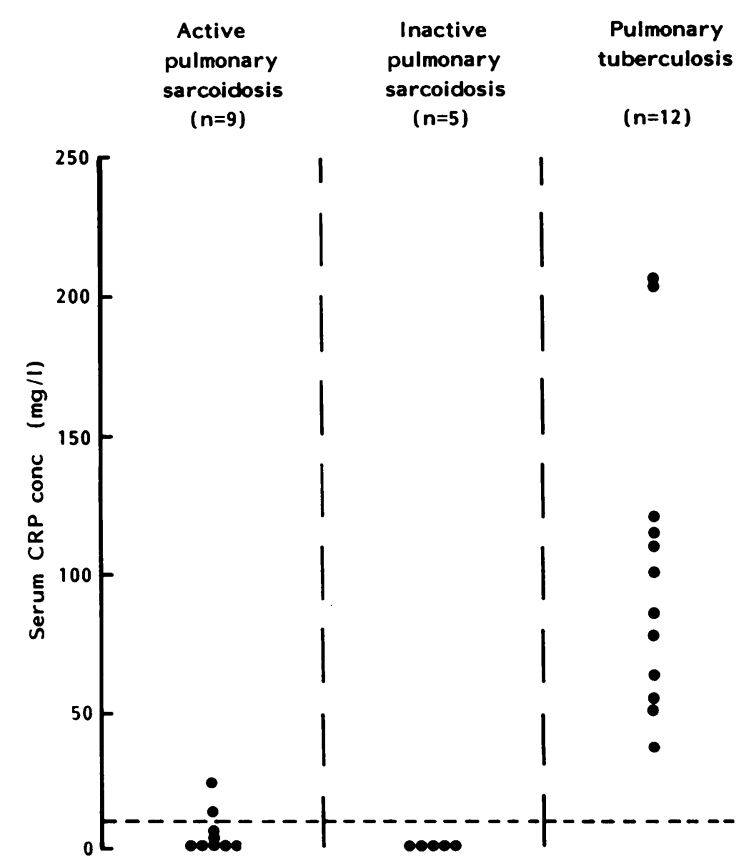

Serum $C$-reactive protein (CRP) concentrations in patients with "active" and "inactive" pulmonary sarcoidosis and active pulmonary tuberculosis (concentration below $10 \mathrm{mg} / \mathrm{l}$ (interrupted line) in $99 \%$ of healthy individuals). 
specific response to most forms of tissue inflammation or damage. ${ }^{15}$ There are, however, several conditions in which, despite unequivocal evidence of active inflammation or tissue damage or both, there is only a minor increase in the serum $\mathrm{C}$-reactive protein concentration, and in many cases it may even remain normal in the face of severe disease. These conditions include systemic lupus erythematosus, scleroderma, ulcerative colitis, and dermatomyositis. ${ }^{16-20}$ In contrast, intercurrent microbial infection does provoke a major $\mathrm{C}$-reactive protein response in all these conditions. ${ }^{16-20}$

The observations reported here would indicate that active pulmonary sarcoidosis should also be included in this group of conditions associated with minor or no increase in serum $\mathrm{C}$-reactive protein concentration despite evidence of ongoing tissue inflammation (that is, alveolitis). The mechanisms for this apparently selective failure of the acute phase response of $C$ reactive protein are not known but, in view of the likely complexity of the pathways that mediate induction of the response, it is possible that some routes are inoperable. The inbred mouse strain $\mathrm{NZB} / \mathrm{W}$, which develops genetically determined autoimmune disease similar to lupus, behaves just like human patients with systemic lupus erythematosus with respect to its acute phase responses; and there may thus be a genetic basis for the phenomenon. ${ }^{21}$ In patients with pulmonary sarcoidosis this phenomenon may reflect the differences in immune responsiveness observed between the peripheral blood compartment and the lung. For example, while bronchoalveolar mononuclear cells have been reported to release increased amounts of interleukin$1,{ }^{6}$ peripheral blood monocytes from patients with sarcoidosis release less IL-1 than do controls. ${ }^{22}$

The other non-specific index of the presence of tissue inflammation is the erythrocyte sedimentation rate. Since this is largely determined by the concentration of proteins (for example, immunoglobulins) which do not reflect the intensity of the acute phase response, and hence IL-1 production, ${ }^{23}$ the aim of this study was not simply to compare serum Creactive protein concentrations and erythrocyte sedimentation rates.

Whatever the mechanism for the absence of a strong C-reactive protein response in active pulmonary sarcoidosis, this difference in the behaviour of C-reactive protein may help to distinguish pulmonary sarcoidosis from conditions which it may mimic and which are known to induce an acute phase response-for example, pulmonary tuberculosis.

We thank Syva Company for kindly providing the serum C-reactive protein assay kits.

\section{References}

1 Mitchell DN, Scadding JG. Sarcoidosis. Am Rev Respiefs Dis 1980;110:774-802.

2 Crystal RG, Roberts WC, Hunninghake GW, Gadek JE듬 Fulmer JD, Line BR. Pulmonary sarcoidosis: a diseasen characterised and perpetuated by activated lungD T-lymphocytes. Ann Intern Med 1980;94:73-94.

3 Hunninghake GW, Crystal RG. Pulmonary sarcoidosisê a disorder mediated by excess helper T-lymphocyt $\vec{B}$ activity at sites of disease activity. $N$ Engl $J$ Med 1981;305:429-34.

4 Gery I, Waksman BH. Potentiation of T-lymphocyte response to mitogens. II. The cellular source of poten $\vec{x}$ tiating mediator(s). J Exp Med 1972;136:143-51.

5 Dinarello CA. Interleukin-1 and the pathogenesis of the acute phase response. $N$ Engl J Med 1984;311:1413-8

6 Hunninghake GW. Release of Interleukin-1 by alveolaw macrophages of patients with active pulmonary sarcoidosis. Am Rev Respir Dis 1984;129:569-72.

7 Pepys MB, Baltz ML. Acute phase proteins with speciat reference to $C$ reactive protein and related protein (pentraxins) and serum amyloid A protein. Adv Immux nol 1983;34:141-212.

8 Keogh BA, Hunninghake GW, Line BR, Crystal RG The alveolitis of pulmonary sarcoidosis: evaluation of natural history and alveolitis-dependent changes in lung function. Am Rev Respir Dis 1983;128:256-65.

9 Hudspith BN, Flint FC, Geraint-James D, Brostoff J⿳亠丷厂犬 Johnson NMcI. Lack of immune deficiency in sarcoid osis: compartmentalisation of the immune response Thorax 1987;42:250-5.

10 Winterbauer RH, Hutchinson JF. Use of pulmonar, function tests in the management of sarcoidosis. Ches $\vec{t}$ 1980;78:640-7.

11 International Committee for Standardisation in $\mathrm{Hae}^{\mathrm{O}}$ matology. Reference method for the erythrocyte sedis mentation rate (ESR) test on human blood. $\mathrm{Br} \mathrm{J} \mathrm{Hae} \underline{\mathrm{O}}$ matol 1973;23:671-3.

12 Friedland J, Silverstein E. A sensitive fluorometric assaý for serum converting enzyme. Am J Clin Patho $\mathbb{B}$. 1976;66:416-24.

13 Shine B, De Beer FC, Pepys MB. Solid phase radio immunoassay for human $\mathrm{C}$ reactive protein. Clin Chim Acta 1981;117:13-23.

14 Yorston D, Whicher J, Chambers R, Klouda P, Easty DD The acute phase response in acute anterior uveitis Trans Ophthalmol Soc UK 1985;104:166-70.

15 Hind CRK, Pepys MB. Acute phase proteins. In: Lesso P MH, Lee TH, Kemeny DM, eds. Allergy. 2nd ed. ChiN cester: Wiley 1987:237-53.

16 Pepys MB, Lanham JG, De Beer FC. C reactive proteing in SLE. Clin Rheum Dis 1982;8:91-103.

17 Hind CRK, Ng SC, Feng PH, Pepys MB. Serum C reac을 tive protein measurement in the detection of inter current infection in Oriental patients with systemic lupus erythematosus. Ann Rheum Dis 1985;44:260-1.

18 Whicher JT, Martin MFR, Dieppe PA. Absence of pros taglandin stimulated increase in acute phase protein in systemic sclerosis. Lancet 1980;ii:1187-8.

19 Fagan EA, Dyck RF, Maton PN, et al. Serum levels of CRP in Crohn's disease and ulcerative colitis. Eur $\$$ Clin Invest 1982;12:351-9. 
20 Haas RH, Dyck RF, Dubovitz V, Pepys MB. CRP in childhood dermatomyositis. Ann Rheum Dis 1982;41:483-5.

21 Rordorf C, Schnebli HP, Baltz ML, Tennent GA, Pepys MB. The acute phase response in $(N Z B \times N Z W) F 1$ and $M R L / l$ mice. $J$ Exp Med 1982;156:1268-73.

22 Hudspith BN, Brostoff J, McNicol MW, Johnson NMcI.
Anergy in sarcoidosis: the role of interleukin-1 and prostaglandins in the depressed in vitro lymphocyte response. Clin Exp Immunol 1984;57:324-30.

23 Pepys MB. Acute phase phenomena. In: Cohen AS, ed. The science and practice of clinical medicine: rheumatology and immunology. New York: Grune and Stratton, 1979:85-9. 